\title{
Treatment of Coking Wastewater Using Sorption Processes
}

\author{
Piotr Bargieł ${ }^{*}$, Magdalena Zabochnicka-Świątek', Paweł Wolski' \\ 1 Faculty of Infrastructure and Environment, Czestochowa University of Technology, ul. Brzeznicka 60a, \\ 42-200 Częstochowa, Poland \\ * Corresponding author's e-mail: piotr.bargiel@pcz.pl
}

\begin{abstract}
Adsorption is one of the basic surface phenomena involving saturation of the adsorbent surface with adsorbate molecules located near the adsorbent-adsorbate interface. The processes that are accompanied by the accumulation of adsorbate molecules on the surface are different from absorption, which is related to absorbing molecules into the whole mass and requires diffusion into the interior. If both processes can occur simultaneously, this phenomenon is called sorption. The aim of the present study was to characterize the sorption properties of selected sorbents and to assess the possibility of their application to support the treatment of coking wastewater from ammonium nitrogen, phenol, and TOC. The scope of the study included the examinations of sorption properties of selected sorbents (coal dust, coke dust, biochar), physicochemical tests of coking wastewater after biological treatment, as well as the examinations aimed to determine the dose of adsorbents and time needed to establish the equilibrium state of the process. The results obtained were analyzed for the effect of dose and contact time on the pollutant removal efficiency. The literature describes the efficiency of ammonium nitrogen removal from wastewater using chemical processes. However, there is a lack of studies on the removal of ammonium nitrogen, phenol, and TOC from industrial (coking) wastewater. The conducted study aimed to develop an alternative solution to the currently used conventional methods of removing high concentrations of pollutants from wastewater.
\end{abstract}

Keywords: coking wastewater, wastewater treatment, sorption, biochar.

\section{INTRODUCTION}

The dynamic development of coke production in Poland requires the application of effective methods for the treatment of coking wastewater. Due to the high content of many chemical compounds, the treatment of coking wastewater poses a number of problems. Therefore, the process is usually divided into several stages [Zhou et al. 2018]. The varied composition of coke wastewater is a major problem in selecting effective treatment methods [Lia et al. 2018]. The main task of industrial process water treatment installations is to reduce the pollutant load to the limits specified in national and European legal regulations [Mielczarek et al. 2011].

Currently, the aim is to implement modern methods of wastewater treatment to obtain the wastewater that meets legal requirements, while at the same time being environmentally friendly [Sizmur et al. 2017]. At present, adsorption processes draw the greatest interest among the techniques used to treat coking wastewater [Mushtaqa et al. 2019]. A wide range of adsorbents of inorganic origin, such as porous glasses, zeolites, and organic materials such as activated carbons, dust, and biochar, and to a lesser extent activated carbon fibers, carbon soot, and ordered mesoporous carbons have been used in this type of processes [Ali et al. 2012]. Dusty and granular adsorbents are most commonly used for the adsorption of pollutants from water [Yaashikaaa et al. 2019]. They are made using charcoal, lignite, anthracite, peat, fruit seeds and stones, nut shells, etc. [Tan et al. 2015].

Phenolic coking wastewater is generated during the process of coal coking and obtaining coal derivatives [Abussaud et al. 2016]. It has a very complex chemical composition. The main substances found in coke wastewater 
include oils, tars, phenols, ammonia, thiocyanates, cyanides, and sulfides. Very high concentrations of pollutants and their toxicity lead to the necessity of multi-stage treatment before being discharged into water, ground, and the sewage system of an external entity. Coal coking and separation of coal products result in the formation of process coke wastewater. This wastewater consists of gas liquor and waters from the coke oven gas treatment plants [Zhanga et al. 2010]. Gas liquor is produced by condensation of water vapor from coke oven gas during its cooling process. The water vapor contained in the gas comes from the moisture and decomposition of coal as well as process steam introduced directly into the gas. Gas liquor is emitted from the watertar condensates formed in gas receivers on the coke battery, gas coolers, dehydrators, and hydraulic closures of gas pipelines. The volume of this wastewater and its chemical composition depends mainly on coal quality and coking technology. The process water from coke oven gas treatment consists of separator water, the process water from desulfurization and ammonia plants, and water from catalytic decomposition of ammonia.

A significant proportion in the quantity and composition of these waters are the water condensates of the coke oven gas produced from process steam directly supplied into the gas system and treatment installation. The process coking wastewater contains high concentrations of oil and tar compounds, ammonia, hydrogen sulfide, and hydrogen cyanide [Tonga et al. 2016].

Since $4^{\text {th }}$ September 2018 , coking plants have been obliged to adapt their wastewater treatment plants to meet the new levels of pollutant limits defined in the best available techniques (BAT 56). This means that, according to BAT 56 conclusions, the coking plants are obliged to ensure the pollutant concentrations in the treated wastewater after biological pretreatment of coking wastewater before discharging it to water or land, reach new levels: COD $<220 \mathrm{mg} / \mathrm{dm}^{3}$; BOD $<20 \mathrm{mg} / \mathrm{dm}^{3}$; free sulfides $<0.1 \mathrm{mg} / \mathrm{dm}^{3}$; thiocyanides $<4 \mathrm{mg} / \mathrm{dm}^{3}$; free cyanides $<0.1 \mathrm{mg} / \mathrm{dm}^{3}$; polycyclic aromatic hydrocarbons (PAHs) $<0.05 \mathrm{mg} / \mathrm{dm}^{3}$; phenols $<0.5 \mathrm{mg} / \mathrm{dm}^{3}$; total nitrogen (sum of ammonia nitrogen, nitrate nitrogen, and nitrite nitrogen) $<15-50 \mathrm{mg} / \mathrm{dm}^{3}$.

\section{METHODOLOGY}

The industrial wastewater (coking wastewater) used in the study was sampled from the installation of Koksownia Częstochowa Nowa Sp. z o.o. The current production capacity of the plant is about $900,000 \mathrm{Mg}$ of coke per year, while the design capacity of the biological wastewater treatment plant is approximately $600 \mathrm{~m}^{3} /$ day. Biological wastewater treatment is based on the classical processes of denitrification and nitrification. Table 1 presents the characteristics of coking wastewater after biological treatment. The tests were conducted in a single-stage system using static contact time.

The coal and coke dust was taken from the installation of Koksownia Częstochowa Nowa Sp. z o.o., whereas the biochar was produced by the company Fluid from Sędziszów. The coal dust was obtained from the dust collection installation at the mill department, whereas the coke dust came from the dust installation at the sorting plant department. Both installations are equipped with a high-efficiency bag filter.

The table above shows that coking wastewater is characterized by very high concentrations of pollutants that are a nuisance for the ground and water environment, which requires searching for more and more advanced technologies for treating such effluents.

The tests on coking wastewater using coal dust, coke dust, and biochar were carried out in two experiments:

- Experiment 1:

- Sorbent dose: $10.0 \mathrm{~g} / 1$

- Wastewater volume: $150 \mathrm{ml}$

- Mixing time: $2 \mathrm{~h}$

- Rotational speed: 300/min

- Time (static contact): $2 \mathrm{~h}$

- Experiment 2:

- Sorbent dose: $10.0 \mathrm{~g} / 1$

- Wastewater volume: $150 \mathrm{ml}$

- Mixing time: $2 \mathrm{~h}$

- Rotational speed: 300/min

- Time (static contact): $22 \mathrm{~h}$

\section{RESULTS AND DISCUSSION}

On the basis of the examinations of porous structure, it can be concluded that the selected dust sorbents can be used as effective adsorbents for coking wastewater pretreatment. Particularly 
Table 1. Characteristics of coking wastewater

\begin{tabular}{|l|c|}
\hline \multicolumn{1}{|c|}{ Parameter } & Concentration, $\mathrm{mg} / \mathrm{dm}^{3}$ \\
\hline Ammonium nitrogen & 100 \\
\hline Total nitrogen & 200 \\
\hline COD & 1500 \\
\hline Phenol & 1000 \\
\hline Thiocyanates & 10 \\
\hline Free cyanides & 5 \\
\hline Free sulfides & 5 \\
\hline
\end{tabular}

Table 2. Characteristics of the porous structure of adsorbents [author's elaboration]

\begin{tabular}{|l|c|c|c|c|}
\hline \multicolumn{1}{|c|}{ Parameter } & Unit & $\begin{array}{c}\text { Coal } \\
\text { dust }\end{array}$ & $\begin{array}{c}\text { Coke } \\
\text { dust }\end{array}$ & Biochar \\
\hline $\mathrm{pH}$ & $\mathrm{pH}$ & 7.9 & 7.2 & 9.6 \\
\hline $\begin{array}{l}\text { Specific surface } \\
\text { area (BET) }\end{array}$ & $\mathrm{m}^{2} / \mathrm{g}$ & 1.82 & 1.12 & 312.00 \\
\hline $\begin{array}{l}\text { Micropore } \\
\text { surface area }\end{array}$ & $\mathrm{m}^{2} / \mathrm{g}$ & 0.26 & 0.39 & 221.00 \\
\hline $\begin{array}{l}\text { External specific } \\
\text { surface area }\end{array}$ & $\mathrm{m}^{2} / \mathrm{g}$ & 1.56 & 0.73 & 91.00 \\
\hline $\begin{array}{l}\text { Macropore } \\
\text { volume }\end{array}$ & $\mathrm{cm}^{2} / \mathrm{g}$ & 0.0026 & 0.0005 & 0.0030 \\
\hline $\begin{array}{l}\text { Mesopore } \\
\text { volume }\end{array}$ & $\mathrm{cm}^{2} / \mathrm{g}$ & 0.0041 & 0.0014 & 0.0574 \\
\hline $\begin{array}{l}\text { Micropore } \\
\text { volume }\end{array}$ & $\mathrm{cm}^{2} / \mathrm{g}$ & 0.0003 & 0.0003 & 0.1071 \\
\hline
\end{tabular}

Table 3. Characteristics of granulometric composition [author's elaboration]

\begin{tabular}{|c|c|c|c|}
\hline Fraction & Coal dust, $\mathrm{g}$ & Coke dust, $\mathrm{g}$ & Biochar, $\mathrm{g}$ \\
\hline $2.00 \mathrm{~mm}$ & 0.00 & 0.00 & 0.00 \\
\hline $1.40 \mathrm{~mm}$ & 0.00 & 0.13 & 0.00 \\
\hline $1.00 \mathrm{~mm}$ & 0.00 & 0.36 & 0.13 \\
\hline $500 \mu \mathrm{m}$ & 1.21 & 5.36 & 0.40 \\
\hline $250 \mu \mathrm{m}$ & 11.32 & 17.60 & 1.02 \\
\hline $100 \mu \mathrm{m}$ & 81.11 & 63.65 & 81.00 \\
\hline$<100 \mu \mathrm{m}$ & 3.85 & 10.54 & 15.33 \\
\hline
\end{tabular}

noteworthy is biochar, which has the largest BET specific surface area, micropore area, and the largest volumes of macropores, mesopores, and micropores. Biochar has a very well-developed porous structure with pores of different sizes and a BET specific surface area of $312 \mathrm{~m}^{2} / \mathrm{g}$. It is also characterized by the largest micropore area $221 \mathrm{~m}^{2} / \mathrm{g}$. Adsorption techniques play an important role in water and wastewater treatment due to their very high efficiency and lack of selectivity in removing various harmful organic compounds. The precondition for effective removal of both soluble and insoluble pollutants (not only organic) in wastewater is the use of adsorbents characterized by a large specific surface area, large pore volume, and appropriate kinetics of pollutant adsorption.

Table 4 shows the initial concentrations of pollutants in wastewater after biological treatment, while Tables 5 and 6 present the test results.

The use of all tested adsorbents led to the reduction in final pollutant concentrations. A reduction of several percent was observed (Fig. 1) already for a contact time of 2 hours. Of all the adsorbents tested, biochar was the most effective, with reductions of $13.6 \%$ for TOC, $1.24 \%$ for ammonium nitrogen, and $18.8 \%$ for phenol. The other adsorbents also showed a high rate of reduction, e.g. in the case of phenol removal, where the use of coal dust resulted in a reduction of $14.04 \%$, while the use of coke dust yielded a $14.44 \%$ reduction.

A further increase in pollutant reduction was observed during further examinations and a contact time of 22 hours (Fig. 2). Again, the

Table 4. Initial pollutant concentrations in wastewater after biological treatment

\begin{tabular}{|l|c|c|}
\hline \multicolumn{1}{|c|}{ Determination } & Unit & Value \\
\hline $\mathrm{pH}$ & - & 11.82 \\
\hline $\mathrm{TOC}$ & $\mathrm{mg} / \mathrm{l}$ & 1250.00 \\
\hline Ammonium nitrogen & $\mathrm{mg} / \mathrm{l}$ & 42.84 \\
\hline Phenol & $\mathrm{mg} / \mathrm{l}$ & 850.00 \\
\hline
\end{tabular}

Table 5. Final pollutant concentrations in wastewater after biological treatment-Experiment 1

\begin{tabular}{|c|c|c|c|c|}
\hline \multirow{3}{*}{ Determination } & \multirow{3}{*}{ Unit } & \multicolumn{3}{|c|}{ Process time: 2 hours } \\
\hline & & \multicolumn{3}{|c|}{ Sorbent dose: $10 \mathrm{~g} / \mathrm{l}$} \\
\hline & & $\begin{array}{l}\text { Coal } \\
\text { dust }\end{array}$ & $\begin{array}{l}\text { Coal } \\
\text { dust }\end{array}$ & $\begin{array}{l}\text { Coal } \\
\text { dust }\end{array}$ \\
\hline $\mathrm{pH}$ & - & 11.90 & 11.51 & 11.90 \\
\hline TOC & $\mathrm{mg} / \mathrm{l}$ & 1190.00 & 1210.00 & 1080.00 \\
\hline $\begin{array}{l}\text { Ammonium } \\
\text { nitrogen }\end{array}$ & $\mathrm{mg} / \mathrm{l}$ & 42.61 & 42.82 & 42.31 \\
\hline Phenol & $\mathrm{mg} / \mathrm{l}$ & 730.70 & 727.30 & 690.20 \\
\hline
\end{tabular}

Table 6. Final pollutant concentrations in wastewater after biological treatment-Experiment 2

\begin{tabular}{|l|c|c|c|c|}
\hline \multirow{2}{*}{ Determination } & \multirow{2}{*}{ Unit } & \multicolumn{4}{|c|}{ Process time: 22 hours } \\
\cline { 3 - 5 } & & \multicolumn{3}{|c|}{ Sorbent dose: $10 \mathrm{~g} / \mathrm{l}$} \\
\cline { 3 - 5 } & $\begin{array}{c}\text { Coal } \\
\text { dust }\end{array}$ & $\begin{array}{c}\text { Coal } \\
\text { dust }\end{array}$ & $\begin{array}{c}\text { Coal } \\
\text { dust }\end{array}$ \\
\hline $\mathrm{pH}$ & - & 11.02 & 10.01 & 10.51 \\
\hline $\mathrm{TOC}$ & $\mathrm{mg} / \mathrm{l}$ & 1170.00 & 1190.00 & 1030.00 \\
\hline $\begin{array}{l}\text { Ammonium } \\
\text { nitrogen }\end{array}$ & $\mathrm{mg} / \mathrm{l}$ & 41.41 & 41.40 & 39.21 \\
\hline Phenol & $\mathrm{mg} / \mathrm{l}$ & 687.50 & 650.00 & 612.50 \\
\hline
\end{tabular}




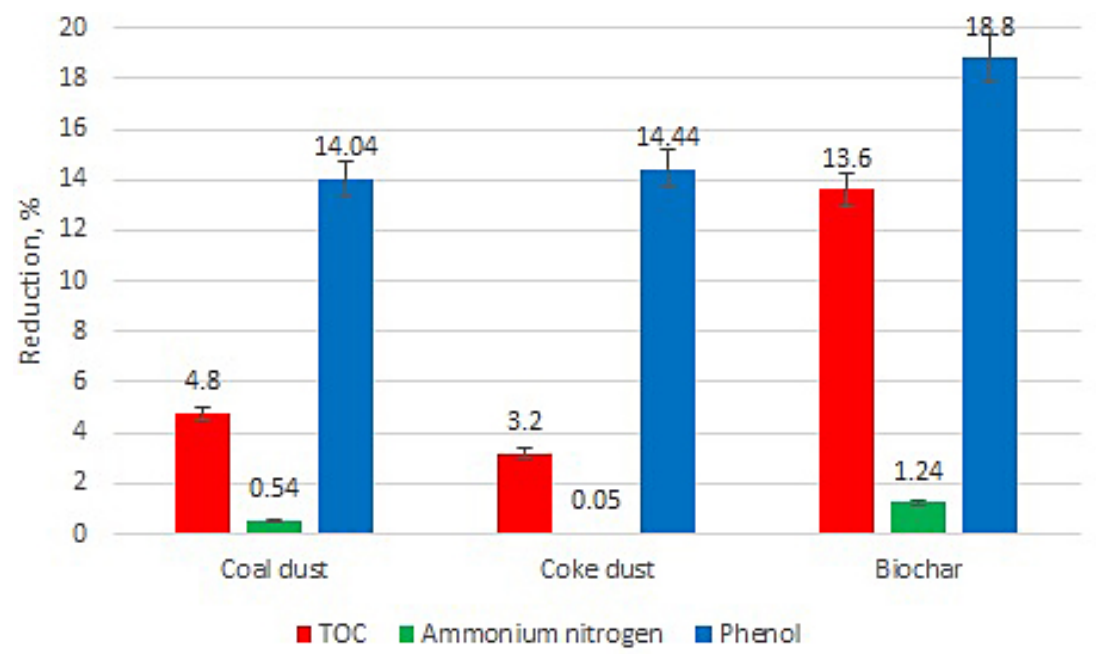

Fig. 1. Reduction in TOC, ammonium nitrogen, and phenol using different adsorbents: Experiment 1

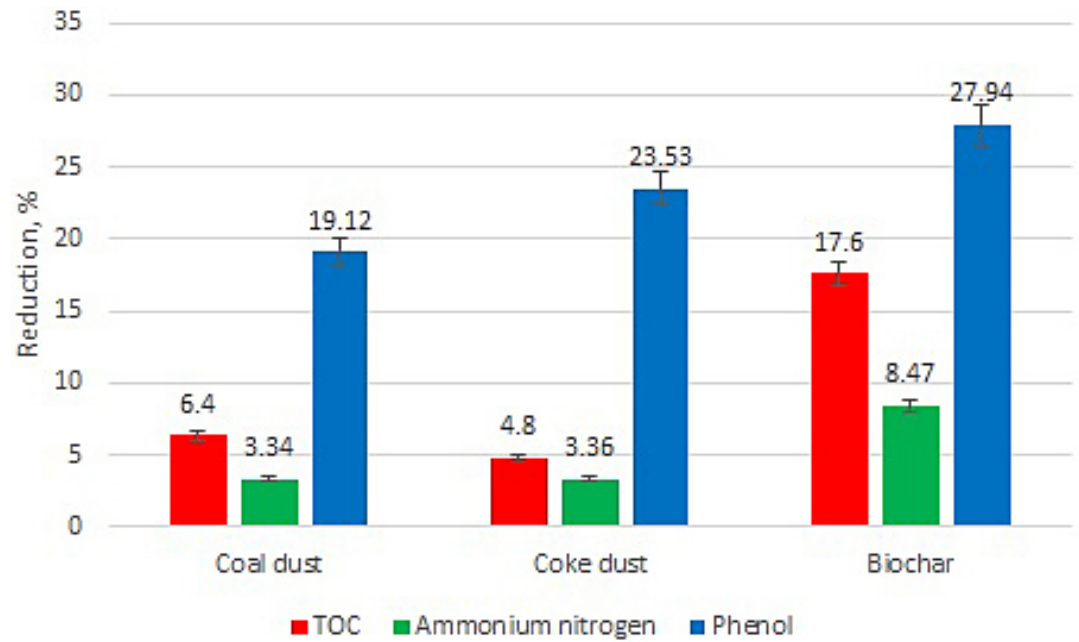

Fig. 2. Reduction in TOC, ammonium nitrogen, and phenol using different adsorbents: Experiment 2

greatest increase in pollutant reduction was observed when biochar was used as an adsorbent. The reduction with respect to the initial pollutant concentration after biological treatment was $17.6 \%$ for TOC, $8.47 \%$ for ammonia nitrogen, and $27.94 \%$ for phenol. The remaining adsorbents (coal dust and coke dust) also showed an increased reduction in pollutants, especially for phenol, with its concentrations reduced by $19.12 \%$ for coal dust and $23.53 \%$ for coke dust.

\section{CONCLUSIONS}

The dynamically developing coke production in Poland requires the use of efficient wastewater treatment methods. Because of the content of many chemical compounds, the treatment of coking wastewater poses many problems. Therefore, the process is usually divided into several stages. The coagulation process is used in the wastewater treatment process.

The precursors to activated carbons used on an industrial scale are primarily fossil coals with varying degrees of metamorphism (from lignites to anthracites), as well as wood, peat, and coconut shells. However, an increasing number of reports can be found in the literature on the preparation of activated carbons by activation of various types of waste materials, both of plant and industrial origin [Nowicki et al. 2016].

The findings of the study lead to the following conclusions:

1. The greatest effectiveness in reducing the pollutant concentrations in wastewater after biological treatment was found for biochar. Its effectiveness was due to the characteristics of its structure, i.e., BET specific surface 
area of $312 \mathrm{~m}^{2} / \mathrm{g}$ and micropore surface area of $221 \mathrm{~m}^{2} / \mathrm{g}$;

2. The highest efficiency was observed for phenol removal and a contact time of 22 hours (Experiment 2), with reductions reaching $19.12 \%$, $23.53 \%, 27.94 \%$ for coal dust, coke dust, and biochar, respectively;

3. The smallest pollutant reduction efficiency was observed for ammonium nitrogen, with reductions of $0.54 \%, 0.05 \%$, and $1.24 \%$ for coal dust, coke dust, and biochar, respectively, for a contact time of 2 hours (Experiment 1). The values obtained were within error.

\section{Acknowledgements}

The research was funded by the project BS/PB-400-301/21

\section{REFERENCES}

1. Abussaud B., Asmaly A.H., Ihsanullah, Saleh A.T., Vinod Kumar Gupta V.K., Tahar Laoui T., Atieh A.M. 2016. Sorption of phenol from waters on activated carbon impregnated with iron oxide, aluminum oxide and titanium oxide. J. Mol. Liq., 213, 351-359.

2. Ali I., Asim M., Khan A.T. 2012. Low cost adsorbents for the removal of organic pollutants from wastewater. J. Environ. Manage., 113, 170-183.

3. Lia J., Yuana X., Zhaoa H., Lia F., Leib Z., Zhang Z. 2018. Highly efficient one-step advanced treatment of biologically pretreated coking wastewater by an integration of coagulation and adsorption proces. Bioresource Technol., 247, 1206-1209.

4. Mielczarek K., Bohdziewicz J. 2011. Performance prediction of ultrafiltration treatment of post-process coke wastewater based on the assumptions of hydraulic filtration resistance model. Arch. Environ. Prot., 37(4), 107-118.

5. Mushtaqa F., Zahida M., Bhattia A.I., Nasirb S., Hussainc T. 2019. Possible applications of coal fly ash in wastewater treatment. J. Environ. Manage., 240, 27-46.

6. Nowicki P., Kaźmierczak-Rażna J., Pietrzak R. 2016. Właściwości fizykochemiczne i sorpcyjne węgli aktywnych otrzymanych przez aktywację skór owoców cytrusowych oraz niskiej jakości węgla brunatnego. Inż. Ochr. Środ., 19(3), 341-352.

7. Sizmur T., Fresno T., Akgül G., Frost H., MorenoJiménez E. 2017. Biochar modification to enhance sorption of inorganics from water. Bioresource Technol., 246, 34-47.

8. Tan X., Liu Y., Zeng G., Wangc X., Hua X., Gu Y., Yang Z. 2015. Application of biochar for the removal of pollutants from aqueous solutions. Chemosphere, $125,70-85$.

9. Tonga K., Lina A., Ji G., Wang D., Wang X. 2016. The effects of adsorbing organic pollutants from super heavy oil wastewater by lignite activated coke. J. Hazard. Mater., 308, 113-119.

10. Yaashikaaa P.R., Kumara P.S., Varjanic S.J., Saravanand A. 2019. Advances in production and application of biochar from lignocellulosic feedstocks for remediation of environmental pollutants. Bioresource Technol., 292, 122-130.

11. Zhanga M.H., Zhao Q.L., Bai X., Ye Z.F. 2010. Adsorption of organic pollutants from coking wastewater by activated coke. Colloids and Surfaces A: Physicochem. Eng. Asp., 362, 140-146.

12. Zhou H., Wei Ch., Zhang F., Liao J., Hu Y., Wu H. 2018. Energy-saving optimization of coking wastewater treated by aerobic bio-treatment integrating two-stage activated carbon adsorption. J Clean Prod, $175,467-476$. 